\title{
PLAC8 wt Allele
}

National Cancer Institute

\section{Source}

National Cancer Institute. PLAC8 wt Allele. NCI Thesaurus. Code C90306.

Human PLAC8 wild-type allele is located in the vicinity of $4 \mathrm{q} 21.22$ and is approximately 24 $\mathrm{kb}$ in length. This allele, which encodes placenta-specific gene 8 protein, may play a role in the modulation of dendritic cell activity. Aberrant expression of the gene may be involved in leukemia relapse. 